\title{
Management of intra-abdominal hypertension during ECMO: Total water-assisted colonoscopy as a step-up minimally invasive treatment, and a literature review
}

\section{(ㄷ)(1) $(-)$}

Authors

Gennaro Martucci ${ }^{1}$, Michele Amata ${ }^{2}$, Fabrizio di Francesco ${ }^{3}$, Mario Traina ${ }^{2}$, Antonio Arcadipane ${ }^{1}$, Roberto Lorusso ${ }^{4,5}$, Antonino Granata²

Institutions

1 Department of Anesthesia and Intensive Care, IRCCSISMETT (Istituto Mediterraneo per i Trapianti e Terapie ad alta specializzazione) Palermo, Italy

2 Endoscopy Service, IRCCS-ISMETT (Istituto Mediterraneo per i Trapianti e Terapie ad alta specializzazione) Palermo, Italy

3 Abdominal Surgery Unit, IRCCS-ISMETT (Istituto Mediterraneo per i Trapianti e Terapie ad alta specializzazione) Palermo, Italy

4 Department of Cardio-Thoracic Surgery, Heart \& Vascular Centre - Maastricht University Medical Centre

5 Cardiovascular Research Institute Maastricht (CARIM), Maastricht University, Maastricht, Netherlands

submitted 24.10.2020

accepted after revision 3.2.2021

\section{Bibliography}

Endosc Int Open 2021; 09: E848-E852

DOI 10.1055/a-1399-8209

ISSN 2364-3722

(c) 2021. The Author(s).

This is an open access article published by Thieme under the terms of the Creative Commons Attribution-NonDerivative-NonCommercial License, permitting copying and reproduction so long as the original work is given appropriate credit. Contents may not be used for commercial purposes, or adapted, remixed, transformed or built upon. (https://creativecommons.org/licenses/by-nc-nd/4.0/)

Georg Thieme Verlag KG, Rüdigerstraße 14,

70469 Stuttgart, Germany

Corresponding author

Antonio Arcadipane, MD, Department of Anesthesia and Intensive Care, IRCCS-ISMETT (Istituto Mediterraneo per i
Trapianti e Terapie ad alta specializzazione), Via tricomi 5,

90133 Palermo, Italy

Fax: +00390912192111

aarcadipane@ismett.edu

\section{ABSTRACT}

Background and study aims During extracorporeal membrane oxygenation (ECMO), intra-abdominal hypertension $(\mathrm{IAH})$ can impair ECMO venous drainage, reducing its ability to provide an adequate oxygenated blood flow. When medical therapy is ineffective in managing $\mathrm{IAH}$, guidelines recommend a decompressive laparotomy (DL), though the procedure is associated with several complications and poor outcomes.

Patients and methods This was a case series of IAH in patients affected with acute respiratory distress syndrome (ARDS) on veno-venous ( $\mathrm{V}-\mathrm{V}) \mathrm{ECMO}$, in whom we performed total water-assisted colonoscopy (t-WAC) to treat $\mathrm{IAH}$.

Results In three patients who underwent t-WAC, we report a real-time intra-procedural reduction of IAH, normalization of ECMO blood flow, and a reduction of vasopressors and lactates. t-WAC was performed in the context of evident abdominal compartment syndrome with multiorgan failure, and in one case was performed because of IAH and ECMO impairment. One patient was discharged alive, while the other two died of multiorgan failure, although the cause of death was apparently not secondary to IAH.

Conclusions During ECMO, in select cases, T-WAC may represent a first-line non-invasive approach.

\section{Introduction}

Intra-abdominal hypertension (IAH) is frequent in critically ill patients, and can cause abdominal compartment syndrome (ACS), which is a severe complication resulting from an acute and sustained increase in intra-abdominal pressure (IAP) [1].
During extracorporeal membrane oxygenation (ECMO), patients are at risk of IAH due to the severity of their critical illness and the need for multiple transfusions and fluids [2]. Moreover, in the specific setting of ECMO, IAH can impair the venous drainage, reducing its ability to provide an adequate oxygenated blood flow [3]. The ECMO malfunction can be considered an 
Table 1 Values for intra-abdominal pressure, vasopressor needs, and lactates.

\begin{tabular}{|c|c|c|c|c|c|c|c|c|c|c|}
\hline Case & $\begin{array}{l}\text { Cause } \\
\text { of ARDS }\end{array}$ & $\begin{array}{l}\text { Cannu- } \\
\text { lation }\end{array}$ & $\begin{array}{l}\text { IAH } \\
\text { before } \\
\text { tWAC } \\
\text { (mmHg) }\end{array}$ & $\begin{array}{l}\text { IAH after } \\
\text { tWAC } \\
(\mathrm{mmHg})\end{array}$ & $\begin{array}{l}\text { IAH } \\
\text { Variation } \\
(\mathrm{mmHg})\end{array}$ & $\begin{array}{l}\text { Lactates } \\
\text { pre- } \\
\text { tWAC } \\
\text { (mmol|L) }\end{array}$ & $\begin{array}{l}\text { Lactates } \\
\text { post- } \\
\text { tWAC } \\
\text { (mmol|L) }\end{array}$ & $\begin{array}{l}\text { Norepi- } \\
\text { nephrine } \\
\text { pre- tWAC } \\
\text { (mcg|kg| } \\
\text { min) }\end{array}$ & $\begin{array}{l}\text { Norepi- } \\
\text { nephrine } \\
\text { post-tWAC } \\
\text { (mcg|kg } \\
\text { |min) }\end{array}$ & $\begin{array}{l}\text { Outcome } \\
\text { (days after } \\
\text { last endos- } \\
\text { copy) }\end{array}$ \\
\hline 1 & $\begin{array}{l}\text { Poly- } \\
\text { trauma }\end{array}$ & $\begin{array}{l}\text { Femoro- } \\
\text { jugular }\end{array}$ & 20 & 9 & 11 & 5.71 & 2.85 & 0.15 & 0.08 & $\begin{array}{l}\text { Death } \\
\text { ( } 65 \text { days) }\end{array}$ \\
\hline 2 & H1N1 & $\begin{array}{l}\text { Femoro- } \\
\text { jugular }\end{array}$ & 13 & 3 & 10 & 1.12 & 0.93 & 1 & 1 & $\begin{array}{l}\text { Discharge } \\
\text { (37 days) }\end{array}$ \\
\hline 3 & $\begin{array}{l}\text { Pneumo- } \\
\text { cystis } \\
\text { jirovecii }\end{array}$ & $\begin{array}{l}\text { Femoro- } \\
\text { femoral }\end{array}$ & 16 & 12 & 4 & 1.69 & 1.18 & 0.1 & 0.02 & $\begin{array}{l}\text { Death } \\
\text { (15 days) }\end{array}$ \\
\hline
\end{tabular}

ARDs, acute respiratory distress syndrome; IAH, intra-abdominal hypertension; tWAC, total water-assisted colonoscopy.

aspect of ACS; consequently, the appearance of IAH during ECMO would likely necessitate a personalized approach [4].

Decompressive laparotomy $(\mathrm{DL})$ is the recommended next step when medical treatment fails in IAH [5]. However, as a surgical procedure, it can be burdened by severe complications, such as bleeding and intra-abdominal infections, and may not always be feasible, especially in unstable patients [6]. Data on DL during ECMO show a still high rate of mortality; consequently, as in other complications during ECMO, any effort to treat them noninvasively should be carried out, and gastroenterology with advanced endoscopy has proved to be a fertile field for this purpose.

Considering the absence of a clear standardization in the management of ECMO patients with IAH, total water-assisted colonoscopy (t-WAC) has been applied as a less-invasive approach to avoid overdistention of the colon and reduce the pressure gradient [7].

\section{Patients and methods}

We present a case series of three patients on veno-venous (V-V) ECMO with IAH treated with t-WAC, which effectively produced a successful reduction in IAP.

The IAP was measured at the end of expiration, with the patient in a supine position, using a catheter through the bladder with an instillation of $25 \mathrm{~mL}$ of sterile saline, and the transducer zeroed at the mid-axillary line [8]. Patient characteristics and peri-procedural values are detailed in > Table 1 and $>$ Table 2.

\section{Results}

\section{Case 1}

This patient was a 16-year-old man on V-V ECMO for polytrauma with bilateral pneumothorax and pulmonary contusions, cerebral intra-parenchymal hemorrhage, multiple fractures (maxilla and mandibula with dental avulsion, thoracic vertebraefrom T4 to T7 and pelvis). His clinical course was complicated by acute renal failure requiring continuous renal replacement therapy (CRRT), hospital-acquired pneumonia due to
Table 2 Summary of patient characteristics.

\begin{tabular}{|c|c|c|c|}
\hline & Case 1 & Case 2 & Case 3 \\
\hline Sex & Male & Male & Male \\
\hline Age, years & 16 & 43 & 43 \\
\hline Weight (kg) & 63 & 81 & 58 \\
\hline Height (cm) & 170 & 175 & 165 \\
\hline BMI & 22 & 26 & 21 \\
\hline Saps II at admission & 31 & 43 & 64 \\
\hline Sofa score at admission & 7 & 8 & 7 \\
\hline PRESERVE score & 4 & -2 & 4 \\
\hline RESP score & -3 & 1 & -2 \\
\hline Pre-ECMO length of hospital stay, days & 30 & 3 & 9 \\
\hline Pre-ECMO mechanical ventilation, days & 30 & 2 & 7 \\
\hline Pre-ECMO P/F ratio & 46 & 1 & 56 \\
\hline Murray score & 3.75 & 1 & 3.75 \\
\hline Pre-ECMO creatinine (mg/dL) & 0.58 & 1.62 & 0.64 \\
\hline Hematocrit (\%) & 27 & 19 & 28.5 \\
\hline \multicolumn{4}{|l|}{ Type of Cannulation } \\
\hline Drainage $(F)$ & 25 & 25 & 25 \\
\hline Return & 19 & 21 & 23 \\
\hline Mean hematocrit value (\%) & 27.57 & 23.04 & 30.25 \\
\hline Total PRBC transfused (unit) & 69 & 16 & 27 \\
\hline Prone position during ECMO (yes/no) & No & Yes & Yes \\
\hline CRRT & Yes & Yes & Yes \\
\hline \multicolumn{4}{|c|}{$\begin{array}{l}\text { BMI, body mass index; PRESERVE, PRedicting dEath for SEvere ARDS on VV- } \\
\text { ECMO; RESP, Respiriatory ECMO Survival Prediction; ECMO, extracorporeal } \\
\text { membrane oxygenation; PRBC, packed red blood cells; CRRT, continuous re- } \\
\text { nal replacement therapy. }\end{array}$} \\
\hline
\end{tabular}


multidrug-resistant germs (Klebsiellapneumoniae, Acinetobacter baumanii, E. Coli, extended-spectrum beta lactamases, and Pseudomonas aeruginosa), and two episodes of massive hemothorax treated with thoracoscopic surgical evacuation, and subsequently evolving into pleural empyema.

On the 37th day after admission, during a new episode of septic shock, the patient developed IAH up to $20 \mathrm{~mm} \mathrm{Hg}$, associated with instability of the ECMO flows, hemodynamics, and lactates up to $5.71 \mathrm{mmol} / \mathrm{L}$. Vasopressors (norepinephrine and vasopressin), and intense volume filling with repeated packed red blood cell (PRBC) transfusions were needed. A CT scan showed overdistension of the colic frame and hydroplane levels. Advanced medical treatment was implemented focusing on reduction of IAP: neuromuscular blockade with rocuronium in continuous infusion was started, gastric content was evacuated by nasogastric tube, fluids were reduced favoring PRBC, and CRRT was continued. Considering the unstable clinical picture, we proceeded with t-WAC prior to any surgical decompression. The procedure was effective, providing reduction in the IAP $(9 \mathrm{~mm} \mathrm{Hg})$ and lactates $(2.85 \mathrm{mmol} / \mathrm{L})$, restoring ECMO blood flow, and reducing the vasopressor dosage. In the following days, we observed the reappearance of canalization. Due to the septic complications and lung failure, the patient required continuous ECMO and CRRT support and, unfortunately, died on the 111th ECMO day.

\section{Case 2}

A 43-year-old man presented with acute ARDS due to human influenza A (H1N1) virus, requiring CRRT for hemodynamic instability and oliguria, and three endoscopic sessions for bleeding from a gastric stress ulcer.

On the 11th day, abdominal distension was observed, with impaired ECMO flow. IAP was $13 \mathrm{~mm} \mathrm{Hg}$, the lactate level was $1.12 \mathrm{mmol} / \mathrm{L}$, and no hemodynamic instability was observed, although it was necessary to reduce the blood flow from 5.5 to $4.3 \mathrm{~L} / \mathrm{min}$ while the patient was entirely ECMO-dependent. Strategies to stabilize and eventually increase the ECMO blood flow were started: The patient was fully sedated and paralyzed to reduce diaphragm swinging and consequent negative pressures in the drainage cannula and fluids were administered judiciously since echocardiography showed a fully replete vena cava without any change in respiratory activity.

In this case, t-WAC was performed to prevent the development of ACS because the team was not able to deliver proper ECMO support. IAP dropped to $3 \mathrm{~mm} \mathrm{Hg}$, restoring the blood flow to 5.5. The clinical course in the Intensive Care Unit (ICU) was complicated by the development of hospital-acquired pneumonia and severe sepsis due to carbapenemase-producing multidrug-resistant Klebsiella pneumoniae. After adequate antibiotic therapy, it was possible to proceed with weaning from ECMO support on the 19th day, weaning from CRRT on the 31st day, and discharge from the ICU on the 37th day.

\section{Case 3}

A 43-year-old man with a recent diagnosis of HIV was placed on V-V ECMO for Pneumocystis jirovecii pneumonia. Septic shock secondary to a bloodstream infection due to Enterococcus fae- cium occurred. We subsequently observed a new onset of anasarca, ascites, and bilateral pleural effusion requiring thoracic drainage and, subsequently, complicated by hemothorax.

On the 4th ECMO day, IAH $(\mathrm{IAP}=16 \mathrm{~mm} \mathrm{Hg})$ occurred, requiring an increase of norepinephrine, full sedation and neuromuscular blockade. The septic shock picture prompted the use of CRRT to manage fluids and reduce overload. The blood ECMO flow become constantly inadequate, so after all the explored medical strategies revealed to be ineffective, a new drainage cannula was placed at the jugular level (becoming a femoral-jugular-jugular design). With the abdominal picture, this was not yet sufficient to restore adequate drainage, and continuous fluid administration as well as transfusions were needed to keep the patient saturated (through the ECMO blood flow) at a level compatible with life. As rescue, we performed t-WAC, and the IAP decreased to $12 \mathrm{~mm} \mathrm{Hg}$. On the 7th day, abdominal infection with Clostridium difficile developed, with the appearance of paralytic ileus and a new ACS framework: lactates up to $5.92 \mathrm{mmol} / \mathrm{L}$, further increase in norepinephrine, and continuing acute renal failure requiring CRRT. An abdominal CT scan revealed the presence of focal ischemia in the right colon and rectum and also in the liver, kidney, and spleen. Despite the high surgical risk, the patient underwent exploratory/decompressive laparotomy and resection of the ischemic colon. The procedure was effective, with ACS resolution and reduction in lactates and norepinephrine, but the sepsis never resolved and the patient died on the 20th day of ECMO support.

\section{Discussion}

This series shows the potential feasibility and effectiveness of the procedure in this setting, even though the mortality in cases of ACS remains high [9].

The survival rate in cases of IAH during ECMO is still extremely variable among centers worldwide, as we demonstrated in a systematic review of the scant literature on the subject ( $>$ Table 3). A standardized approach is lacking in this setting, also considering that the values adopted to evaluate the ACS grade may be inadequate when the ECMO drainage cannula does not reach proper flow due to compressed abdomen [10].

A less-invasive solution, such as t-WAC, could be a therapeutic alternative. T-WAC was first introduced in diagnostic endoscopy because its principal potential benefits included higher cecal intubation rates, lower sedation requirements, and lower patient pain scores, especially in unsedated procedures [11], as well as an increase in the adenoma detection rates.

Unlike an "open" abdomen extra-visceral decompression, such as laparotomy, t-WAC is a minimally invasive technique that provides visceral intraluminal decompression, with easy reproducibility and without serious side effects. Nonetheless, its initial diagnostic function should not be underestimated because it may also contribute to diagnosing intraluminal colonic lesions that may be neglected even with laparotomy. Technically, using a standard or pediatric diagnostic video colonoscope (CF-H 190 L and PCF-H 190 L, Olympus Europe, Hamburg, Germany) and generally with the addition of a standard irrigation pump, t-WAC provides intraluminal instillation of $\mathrm{NaCl} 0.9 \%$, 
Table 3 Summary of studies included in the systematic review.

\begin{tabular}{|c|c|c|c|c|c|c|c|c|c|c|c|c|}
\hline $\begin{array}{l}\text { Au- } \\
\text { thor, } \\
\text { year }\end{array}$ & Journal & $\begin{array}{l}\text { Study } \\
\text { De- } \\
\text { sign }\end{array}$ & $\begin{array}{l}\text { Pa- } \\
\text { tients }\end{array}$ & $\begin{array}{l}\text { ECMO } \\
\text { Config- } \\
\text { uration }\end{array}$ & $\begin{array}{l}\text { Cannu- } \\
\text { lation }\end{array}$ & $\begin{array}{l}\text { ECMO } \\
\text { Indica- } \\
\text { tion }\end{array}$ & Age & $\begin{array}{l}\text { Treat- } \\
\text { ment }\end{array}$ & $\begin{array}{l}\text { Reason for } \\
\text { IAH Treat- } \\
\text { ment }\end{array}$ & $\begin{array}{l}\text { Resolu- } \\
\text { tion of } \\
\text { IAH }\end{array}$ & $\begin{array}{l}\text { ECMO } \\
\text { LOS, } \\
\text { days }\end{array}$ & $\begin{array}{l}\text { Sur- } \\
\text { vival }\end{array}$ \\
\hline $\begin{array}{l}\text { Fed- } \\
\text { dy, } \\
2016\end{array}$ & $\begin{array}{l}\text { Anes- } \\
\text { thesiol } \\
\text { Inten- } \\
\text { sive } \\
\text { Ther }\end{array}$ & $\begin{array}{l}\text { Case } \\
\text { Series }\end{array}$ & 3 & $V-V$ & $\begin{array}{l}2 \text { Ava- } \\
\text { lon, } 1 \\
\text { femoro- } \\
\text { jugular }\end{array}$ & $\begin{array}{l}\text { ARDS } \\
\text { due to } \\
\text { severe } \\
\text { pan- } \\
\text { creatitis }\end{array}$ & $30-46^{1}$ & $\begin{array}{l}\text { Conser- } \\
\text { vative }\end{array}$ & $\begin{array}{l}\text { MOF, im- } \\
\text { pairment } \\
\text { of ECMO } \\
\text { drainage }\end{array}$ & Yes & $\begin{array}{l}26.5, \\
9.1,15\end{array}$ & $100 \%$ \\
\hline $\begin{array}{l}\text { Glo- } \\
\text { wka, } \\
2018\end{array}$ & $\begin{array}{l}\text { J Crit } \\
\text { Care }\end{array}$ & $\begin{array}{l}\text { Retro- } \\
\text { spec- } \\
\text { tive }\end{array}$ & 11 & $\begin{array}{l}4 \mathrm{~V}-\mathrm{V} \\
7 \mathrm{~V}-\mathrm{A}\end{array}$ & NA & $\begin{array}{l}4 \text { ARDS, } \\
1 \text { trau- } \\
\text { ma, } \\
3 \text { eCPR, } \\
2 \mathrm{MI}, \\
1 \text { PCS }\end{array}$ & $36-80^{1}$ & $\mathrm{DL}$ & $\begin{array}{l}\text { Clinical } \\
\text { decision } \\
\text { High vol- } \\
\text { ume resus- } \\
\text { citation in } \\
\text { the pre- } \\
\text { vious } 24 \mathrm{~h}\end{array}$ & $\begin{array}{l}\text { Unspeci- } \\
\text { fied. SOFA } \\
\text { score re- } \\
\text { duced in } \\
1 / 11\end{array}$ & NA & $\begin{array}{l}3 / 11 \\
27 \%\end{array}$ \\
\hline $\begin{array}{l}\text { Bou- } \\
\text { los, } \\
2020\end{array}$ & ASAIO J & $\begin{array}{l}\text { Retro- } \\
\text { spec- } \\
\text { tive }\end{array}$ & 9 & $V-V$ & $\begin{array}{l}6 \text { fe- } \\
\text { moro- } \\
\text { jugular, } \\
3 \text { femor- } \\
\text { ofemor- } \\
\text { al }\end{array}$ & $\begin{array}{l}6 \text { ARDS, } \\
2 \text { DLTx, } \\
1 \text { hypo- } \\
\text { thermia }\end{array}$ & $\begin{array}{l}44(31- \\
55)\end{array}$ & $\mathrm{DL}$ & $\begin{array}{l}\text { Hypervole- } \\
\text { mia (44\%) } \\
\text { Bleeding } \\
(33 \%) \\
\text { Bowel } \\
\text { ischemia } \\
(22 \%)\end{array}$ & Yes & 14 & $\begin{array}{l}5 / 9 \\
56 \%\end{array}$ \\
\hline
\end{tabular}

Given the scant available studies on PubMed, only two retrospective studies reported the efficacy of DL, with different outcomes in terms of definitive results. the other report showed an effective resolution of IAH and higher survival rates with conservative treatment.

ECMO, extracorporeal membrane oxygenation; V-V, veno-venous; V-A, veno-arterial; DL, decompressive laparotomy; IAH, intra-abdominal hypertension; LOS, length of stay; ARDS, acute respiratory distress syndrome; eCPR, extracorporeal cardiopulmonary resuscitation; MI, myocardial infarction; PCS, post-cardiotomyshock; DLTx, double lung transplant; NA, not available.

${ }^{1}$ Age is presented as a minimum and maximum value.

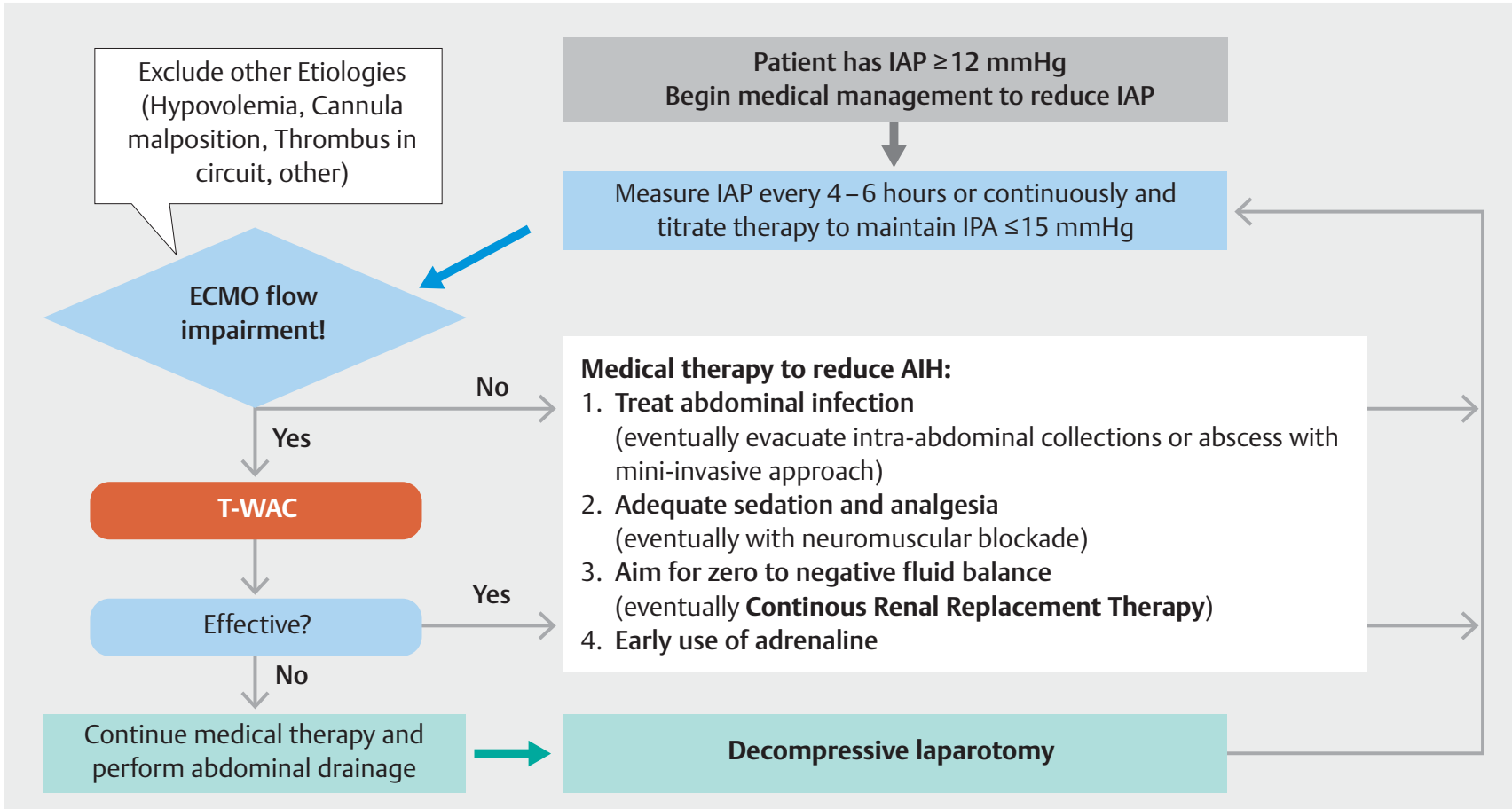

- Fig. 1 Proposed flowchart for the management of intra-abdominal hypertension during ECMO. IAP, intra-abdominal pressure; T-WAC, total water-assisted colonoscopy. 
followed by complete aspiration of the residual intraluminal air and opaque saline water. With water instillation, the proximal colon expands regularly without distention of the upstream intestinal loops that worsen the IAP, as can occur with air. Then, the residual gas and water are completely removed by direct suction during the withdrawal, making this strategy very suitable for critically ill patients, and guaranteeing reduction in wall stress and normalization of intraluminal pressure.

Moreover, the water method can ease the passage of the colonoscope by straightening angulated sections, such as the sigmoid colon, weighing the colon down, and lubricating the interface between the scope and the mucosa. All these characteristics make the t-WAC a perfect solution for patients in mandatory supine position, as in the case of ECMO patients due to the presence of the cannulas.

In addition, in our opinion, small bowel preparation is not mandatory and can be avoided because the purpose of decompressive t-WAC in this setting is solely therapeutic and not diagnostic. Even with the lack of bowel preparation, in expert hands and using a sufficient quantity of saline solution, the goal of the colonoscopy can be technically satisfied by direct and indirect mechanical decompression of major numbers of focal areas of intraluminal air. As a result, we do not believe there is a need to always reach and intubate the cecum, but in our opinion, a sufficient therapeutic effect can be effectively achieved if the intraprocedural IAH measurement reflects a stable reduction in values during the entire withdrawal time. In fact, in our case series, we found a real-time and intraprocedural reduction in IAH during the phase of fluid aspiration through the endoscope and gradual normalization of ECMO blood flow in all the cases. These conditions were deemed parameters of "adequacy" for the procedure.

\section{Conclusions}

In summary, t-WAC, in cases of mild or severe IAH during ECMO, can contribute early and noninvasively to the diagnosis and treatment of colonic distension. This condition is not infrequent during ECMO, either in its veno-venous or veno-arterial configuration, in particular when septic shock, low cardiac output, and fluid overload coexist. It may act as a first step before eventual DL, can be applied as a point-of-care treatment because it does not require the transfer of unstable patients, and does not require adjusting the patient position.

The technical algorithm focused on the DL, as suggested by guidelines, could likely be implemented with the t-WAC as an intermediate point in a more complete "step-up" approach ( Fig.1).

\section{Acknowledgements}

The authors are indebted to Warren Blumberg, science editor at ISMETT, for his help in revising the manuscript.

\section{Competing interests}

The authors declare that they have no conflict of interest.

\section{References}

[1] Reintam Blaser A, Regli A, De Keulenaer B et al. Incidence, risk factors, and outcomes of intra-abdominal hypertension in critically ill patients-a prospective multicenter study (IROI study). Critical Care Med 2019; 47: 535-542

[2] Glowka TR, Schewe JC, Muenster S et al. Decompressive laparotomy for the treatment of the abdominal compartment syndrome during extracorporeal membrane oxygenation support. J Critical Care 2018; 47: $274-279$

[3] Boulos FM, Pasrija C, DiChiacchio L et al. Early decompressive laparotomy for intra-abdominal hypertension following initiation of venovenous extracorporeal membrane oxygenation. ASAIO J 2020; 66: 520-523

[4] De Laet IE, Malbrain M, De Waele J]. A Clinician's guide to management of intra-abdominal hypertension and abdominal compartment syndrome in critically ill patients. Critical care (London, England) 2020; 24: 97

[5] Van Damme L, De Waele J]. Effect of decompressive laparotomy on organ function in patients with abdominal compartment syndrome: a systematic review and meta-analysis. Critical Care (London, England) 2018; 22: 179

[6] Coccolini F, Roberts D, Ansaloni L et al. The open abdomen in trauma and non-trauma patients: WSES guidelines. World J Emerg Surg 2018; 13: 7

[7] Martucci G, Granata A, Traina M et al. Management of abdominal compartment syndrome during extracorporeal membrane oxygenation: water-assisted colonoscopy as early emergency treatment. Minerva anestesiologica 2018; 84: 1108-1109

[8] De Waele J], Cheatham ML, Malbrain ML et al. Recommendations for research from the International Conference of Experts on Intra-abdominal Hypertension and Abdominal Compartment Syndrome. Critical care (London, England) 2009; 64: 203-209

[9] De Waele J, Desender L, De Laet I et al. Abdominal decompression for abdominal compartment syndrome in critically ill patients: a retrospective study. Acta cCinica Belgica 2010; 65: 399-403

[10] Kirkpatrick AW, Roberts D], De Waele J et al. Intra-abdominal hypertension and the abdominal compartment syndrome: updated consensus definitions and clinical practice guidelines from the World Society of the Abdominal Compartment Syndrome. Intensive care medicine 2013; 39: 1190-1206

[11] Anderson JC. Water-assisted colonoscopy. Gastroenterology 2015; 148: 1069-1071 